\title{
Usefulness and reliability of cell free fetal DNA screening for main trisomies in case of atypical profile on first trimester maternal serum screening
}

\author{
Julie Carrara ${ }^{1,2^{*}}$, Alexandre Vivanti ${ }^{1,2}$, Jacques C. Jani ${ }^{3}$, Adèle Demain ${ }^{1}$, Jean-Marc Costa ${ }^{4}$
} and Alexandra Benachi ${ }^{1,2}$

\begin{abstract}
Background: Patients with atypical values of HCG and/or PAPP-A are at higher risk of chromosomal abnormality and vascular complications of pregnancy. The performance of cfDNA in this particular population has not yet been evaluated.

Objectives: The primary objective was to evaluate the usefulness and reliability of cfDNA in screening for trisomy 21, 18 and 13 for patients with HCG $<0.25$ multiple of median (MoM), HCG $>5.0$ MoM and/or PAPP-A $<0.25$ MoM, PAPP-A > 2.5 MoM. The secondary objective was to evaluate the contribution of cfDNA assay for the prediction of pregnancy's vascular complications.

Method: Between June 2016 and July 2017, we analysed a women cohort from all over France who had at least one first trimester serum biomarker outside of normal range, in a retrospective, observational and multicentre study. Patients were included if they had a single pregnancy, normal first trimester ultrasound examination, whatever the result of the combined first trimester screening test was. The cfDNA was analysed by massive parallel sequencing technique. The accuracy of cfDNA assay was evaluated by calculation of sensitivity and specificity, and multivariate regression analysis was used to search for predictive factors for pregnancy's vascular complications.
\end{abstract}

Results: Among the 498 patients who underwent a cfDNA assay in this context, twenty-one (4.2\%) were excluded because of loss to follow-up. Out of 477, test failure occurred for four patients initially, reduced to two patients (0.4\%) after redrawn. CfDNA was positive for Trisomy $21(n=19)$, Trisomy $18(n=6)$ and Trisomy $13(n=1)$ and negative in 449. The sensitivity of cfDNA assay for trisomy 21 screening was 100\% (19/19) (IC 95\% 82.4-100) and specificity 100\% (458/458) (IC 95\% 99.2-100). Among the 447 patients included for prediction of vascular complications, there were four cases of pregnancy induced hypertension and 10 cases of preeclampsia, for which no predictive factor was identified. Intra Uterine growth restriction under 5 th percentile $(n=44,9.8 \%)$ was significantly associated with a low fetal fraction $(\mathrm{OR}=0.87$, IC 95\% 0.79-0.96, $\mathrm{p}=0.006)$.

Conclusion: cfDNA assay is an effective and reliable tool for women with atypical profile of first trimester serum biomarkers.

Keywords: Non-invasive prenatal testing, Cell free fetal DNA, Trisomy 21, Atypical maternal serum biomarkers, High HCG, Low PAPP-A, Intra uterine growth restriction

\footnotetext{
*Correspondence: julie.carrara@aphp.fr

1 Service de Gynécologie-Obstétrique, Hôpital Antoine Béclère, AP-HP,

157 Rue de la Porte de Trivaux, 92140 Clamart, France

Full list of author information is available at the end of the article
}

\section{Introduction}

Cell free fetal DNA (cfDNA) test has widely proved its performance in prenatal screening for trisomy 21, 18 and 13 , in both high risk and general population $[1,2]$.

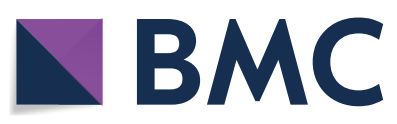

(c) The Author(s) 2019. This article is distributed under the terms of the Creative Commons Attribution 4.0 International License (http://creativecommons.org/licenses/by/4.0/), which permits unrestricted use, distribution, and reproduction in any medium, provided you give appropriate credit to the original author(s) and the source, provide a link to the Creative Commons license, and indicate if changes were made. The Creative Commons Public Domain Dedication waiver (http://creativecommons.org/ publicdomain/zero/1.0/) applies to the data made available in this article, unless otherwise stated. 
In the past few years, its use in clinical practice has been increasing constantly, due to its excellent sensitivity and specificity, added to its non-invasive character. Mainly because of its high cost, it is rarely used for now as a firsttier screening test, and it seems important to evaluate which patients benefit the most of this tool.

When results of first trimester serum biochemical markers [free $\beta$ human chorionic gonadotropin (HCG) and pregnancy-associated plasma protein-A (PAPP-A)] are very different from the average value in general population, the software program calculating the risk cannot take into account the actual values, because they are inadequate to fit in the calculation equation [3]. Therefore, the software applies a truncation model, and uses the most extreme value useable but not the real one. This could lead to an underestimation of the calculated risk, and thus it has been described that these patients with abnormally high or low HCG or PAPP-A values have a higher risk of abnormal karyotypes [3]. These atypical values can contribute to placing the patient in the high risk group after the combined test, but not necessarily if the other criteria are in normal range (age and nuchal translucency at first trimester ultrasound). Thus, we have chosen to study women with first trimester screening test's atypical profile (high or low HCG and PAPP-A rate), whatever the result of the combined test. In this population, it has also been described a higher risk of vascular complications during pregnancy, such as preeclampsia (PE) and intra uterine growth restriction (IUGR) [4-7]. In fact, several authors have suggested that there might be an association between those vascular risks and the fetal fraction of cfDNA [8-12]. It is known that this higher risk of vascular complications mostly concerns patients with high HCG and low PAPP-A, but as there is no data available concerning the link between cfDNA tests and those serum biochemistry atypical values, we chose to include also patients with low HCG and high PAPP-A in the analysis.

The main objective of this study was to evaluate the usefulness and reliability of cfDNA assay in screening for trisomy 21, 18 and 13 for patients with first trimester maternal serum screening's atypical profile. The second objective was to evaluate the contribution of the cfDNA assay in the prediction of pregnancy's vascular complications.

\section{Methods}

\section{Study design}

All cfDNA assays were performed in clinical setting. We conducted a retrospective, multicentric and nationwide study, including women from all over France who underwent a cfDNA assay sent to laboratory CERBA (as this laboratory is one of the few allowed to perform this test in France, and collaborates with medical healthcare practitioners from all over the territory) and who had at least one atypical biochemical marker of first trimester screening test. The inclusion criteria were women with an age of 18 or more, a singleton pregnancy, a normal first trimester ultrasound examination according to French national recommendation [13] (in particular nuchal translucency inferior to 95th percentile for gestational age), a first trimester screening test performed between 11 and 13.6 weeks of gestation (WG), a cfDNA assay, and at least one atypical value of first trimester serum assay (free $3 \mathrm{HCG}<0.25$ multiple of median $(\mathrm{MoM}), \mathrm{HCG}>5.0$ MoM and/or PAPP-A $<0.25$ MoM, PAPP-A $>2.5 \mathrm{MoM}$ ). The cutoff chosen for these values was decided in accordance with the most frequent and clinically relevant values found in literature [3]. Patients who did not do their first trimester ultrasound between 11 and 13.6 WG, as well as patients with second trimester screening test were not included. Patients with a vanishing twin described on early ultrasounds were not included, as it is well known that this could influence the level of HCG and PAPP-A assays, as well as the result of the cfDNA assay [14].

Pregnancy induced Hypertension (PIH) was defined as a blood pressure above 140 and/or $90 \mathrm{mmHg}$ for women without any history of chronic high blood pressure. PE was defined as PIH associated with proteinuria above $0.3 \mathrm{~g} / 24 \mathrm{~h}$. Early PE was defined as PE with delivery before 37 weeks. Intra uterine growth restriction (IUGR) was defined as a birthweight lower than 10th percentile according to the Audipog growth curve [15]. It was considered severe if birthweight was lower than 5 th percentile.

We collected all available computerized data from the selected patients and sent a survey to each health care practitioner who prescribed the cfDNA assay, either by regular mail or e-mail, in order to collect all pregnancy outcomes. In case of no-response or lack of information, the health care practitioners or the patients themselves were questioned by phone. All data were de-identified to ensure patient privacy and confidentiality. In line with French regulations regarding prenatal diagnosis, written informed consent was obtained from all patients. CERBA Laboratory is authorized by the Regional Health Agency to perform these screening tests. This research was approved by The Ethical Review Committee of the French CEROG (submission number CEROG 2018-OBST-0103).

\section{Cell free DNA analysis in maternal plasma}

Maternal blood was collected in two cfDNA BCT Streck ${ }^{\circledR}$ tubes $\left(10 \mathrm{~mL}\right.$ for each) and sent at $+4{ }^{\circ} \mathrm{C}$ to the clinical lab where plasma was isolated within 4 days after collection by a double centrifugation procedure and stored 
frozen at $\leq-70{ }^{\circ} \mathrm{C}$ if not processed immediately. CfDNA in maternal plasma analysis was performed by massively parallel sequencing by using a whole genome approach, either by a home-brew assay as described previously [16] or by using the CE-IVD marked VeriSeq NIPT assay (Illumina ${ }^{\circledR}$, Paris, France) since May 2017 due to the modification of the French regulation. During each run of the experiment, no template controls, plasma pooled from euploid pregnancies, or low positive controls prepared by mixing plasma from nonpregnant women and trisomy 13,18 , or 21 libraries were run simultaneously with the patient samples. Finally, sequence reads were mapped to the UCSC hg19 version of the human genome using Bowtie version 2; Z-scores were calculated for the targeted chromosomes 13,18 , and 21 . The results are expressed as "positive" or "negative" when the experiments fulfilled the following metric criteria: library concentration $7.5 \mathrm{nM}$ or greater, total number of aligned sequence reads nine million or greater and no amplification bias. Estimation of fetal DNA fraction from the plasma of pregnant women was performed either by using sequence read counts alone (referred to as SeqFF) [17] or in combination with fragment size distribution and Y chromosome-based method (VeriSeq NIPT).

\section{Statistical analysis}

Descriptive results are reported as percentages for categorical variables and as median and range for quantitative variables. The performance of the test was characterized by specificity and positive predictive values. Exact $95 \%$ confidence intervals were computed with binomial distribution. Percentages were compared using Chi squared test or Fisher's exact test. Mann-Whitney U test was used to compare medians.

Univariate analysis was used to investigate if vascular pregnancy complications were associated with different factors, such as method of conception (in vitro fertilization or natural conception), ethnicity, multiparity as categorical variables and maternal age (years), weight $(\mathrm{kg})$, gestational age at test (weeks of gestation), HCG and PAPP-A levels, fetal fraction of cell free DNA as continuous numerical variables. Multiple logistic regression analysis was subsequently performed to determine the significant independent contribution of those variables yielding a $\mathrm{p}<0.1$ in the univariate analysis. A subgroup analysis was made to determine if a particular group of patients was at risk of vascular complications (group with elevated level for both PAPP-A and HCG, group with low level for both biomarkers, or mixed).

Data were analyzed with the statistical software MedCalc, version 15.11.4 (Mariarkerke ${ }^{\circledR}$, Belgium) and Excel version 15.0 (Microsoft ${ }^{\circledR}$, Redmond, Wash). A two-sided p-value of less than 0.05 was considered statistically significant.

\section{Results}

Between June 2016 and July 2017, 498 patients with atypical first trimester serum screening profiles met inclusion criteria. We excluded 21 patients (4.1\%) for whom we did not obtain pregnancy outcome. The flowchart of our study is resumed in Fig. 1. The mean maternal age was 32.8 years, the mean weight was $63 \mathrm{~kg}$. The mean gestational age at blood sampling for cfDNA was 15.2 WG (range 11.4-34.1 WG). The mean fetal fraction was 11.0\% (range 1.0-31.8\%). Table 1 resumes the main patient characteristics. In our study cohort, 391 (82\%) patients had a combined risk superior to $1 / 1000$ after first trimester screening.

\section{Test Performance for screening of trisomy 21, 18 and 13}

Out of the 477 patients analyzed, a "no-call" result occurred for four patients initially, reduced to two patients $(0.4 \%)$ after redrawn. For both patients, results were not reported because of a low fetal fraction. One of them gave birth to a phenotypically normal newborn after a normal pregnancy follow up, and the other was diagnosed with a stillbirth at 19 WG in a context of severe fetal growth retardation, with a normal karyotype and vascular abnormalities on the placenta. Among the 477 patients, 26 had a positive cfDNA assay. Twenty-two were confirmed by fetal karyotype after amniocentesis. For the four remaining patients, amniocentesis found a normal karyotype, with a normal pregnancy follow-up. A confined placental mosaicism was confirmed for three of them after birth (for the last one, no placental analysis was performed). In this group of $26 \mathrm{cfDNA}$ positive tests, 25 (96.2\%) of patients had a combined risk superior to $1 / 1000$ after first trimester screening test.

Among the 449 patients with a negative cfDNA assay, 445 were confirmed by a normal karyotype performed during pregnancy for other reason or a normal phenotype at birth. No case of trisomy 21, 18 or 13 was discovered after birth. In four cases, a different chromosomal anomaly was found during pregnancy (one Turner syndrome, two triploïdy and one Di-George syndrome), screened thanks to the systematic routine ultrasound examinations performed at the second and third trimester, as recommended in France for all pregnant women. Overall, the specificity of the cfDNA assay in our study population was $100 \%$ (CI 95\%, 99.2-100.0) for trisomy 21, 99.4\% (CI 95\% 98.2-99.9) for trisomy 18 and 99.8\% (CI 95\% 98.9-100.0) for trisomy 13. Specificity and sensitivity calculations are detailed in Table 2 . 


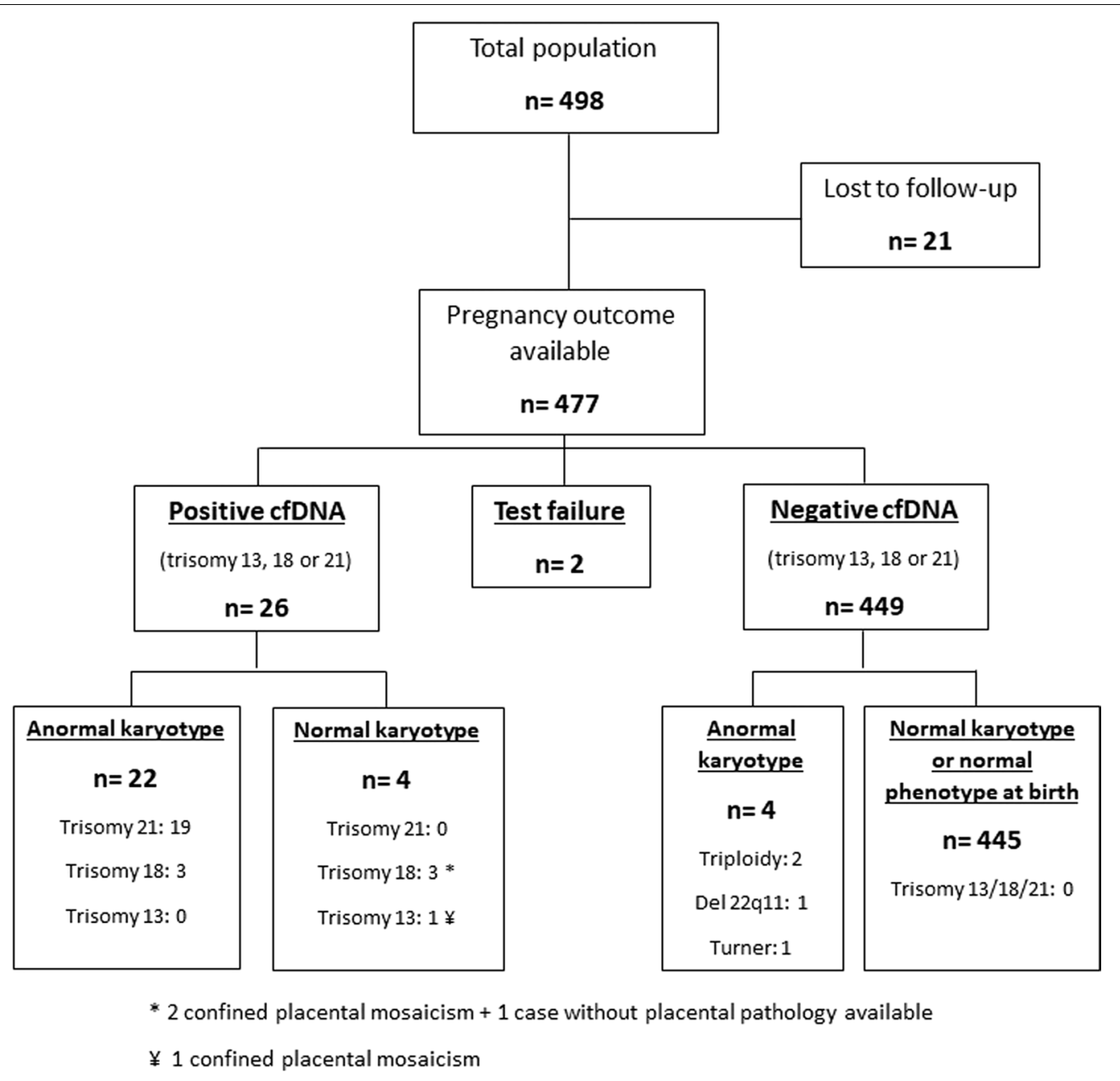

Fig. 1 Flowchart of the study

Table 1 Main characteristics of the study population ( $n=447)$

\begin{tabular}{ll}
\hline Maternal characteristics & Median (range) or $\mathbf{n}(\%)$ \\
\hline Age (years) & $32.8(19.5-46.6)$ \\
Weight (kg) & $63(40-173)$ \\
Multiparous & $266(59.5 \%)$ \\
Ethnicity & \\
Caucasian & $394(88.1 \%)$ \\
Other & $53(11.9 \%)$ \\
Amp induced pregnancy & $25(5.6 \%)$ \\
Auto-immune disease & $24(5.4 \%)$ \\
Anticoagulant treatment & $9(2.0 \%)$ \\
Gestational age (wg) & $15.2(11.4-34.1)$ \\
Fetal fraction $(\%)$ & $11.0(1.0-31.8)$ \\
\hline
\end{tabular}

$A M P$ assisted medical procreation
Test performance for screening of vascular complications For this analysis, we excluded all patients with chromosomal abnormalities (all positive cfDNA assays and the four patients with other chromosomal abnormalities). Indeed, these patients are more exposed to IUGR, as it can often be a part of the fetuses' pathology, and not reflect a placental dysfunction. In addition to that, most patients of this group asked for termination of pregnancy, which occurred in most cases early in pregnancy according to French regulation.

Within the 447 remaining patients, four cases $(0.9 \%)$ of PIH, 10 cases $(2.2 \%)$ of PE and five cases $(1.1 \%)$ of early PE were reported. For these events, no predictive factor was identified in the univariate or multivariate analysis. In the subgroup analysis, there was a trend of correlation between PE and the subgroup of low levels for both 
Table 2 Performance of cfDNA assay for screening of trisomies 13, 18, 21

\begin{tabular}{|c|c|c|}
\hline & Sensitivity & Specificity \\
\hline Trisomy 21 & $19 / 19=100 \%(C \mid 95 \% 82.4-100)$ & $458 / 458=100 \%(C I 95 \% 99.2-100)$ \\
\hline Trisomy 18 & $3 / 3=100 \%(C l 95 \% 29.2-100)$ & $471 / 474=99.4 \%(C l 95 \% 98.2-99.9)$ \\
\hline Trisomy 13 & $0 / 0$ & $476 / 477=99.8 \%(C l 95 \%$ 98.9-100) \\
\hline
\end{tabular}

$\mathrm{Cl}$ confidence interval

PAPP-A and HCG, compared to the group of both elevated levels or mixed, but it did not reach statistical significance (Fig. 3).

IUGR concerned 65 patients (14.5\%), for which a statistical correlation was made with maternal age (OR 1.08, CI 95\% 1.02-1.16, $\mathrm{p}=0.015$ ), PAPP-A level (OR 0.37, CI 95\% 0.24-0.57, $\mathrm{p}<0.0001)$ and medically assisted procreation (OR 4.26, CI 95\% 1.54-11.75, $\mathrm{p}=0.005$ ). No association with fetal fraction calculated in cfDNA assay was observed (OR 0.95, CI 95\% 0.87-1.02, $\mathrm{p}=0.18$ ). On the other hand, severe IUGR under 5th percentile $(\mathrm{n}=44,9.8 \%)$ were significantly associated with a low fetal fraction in cfDNA assay $(\mathrm{OR}=0.87$, ICI 95\% 0.79$0.96, \mathrm{p}=0.006)$, in addition to gestational age at cfDNA assay (OR $=1.12$, CI 95\% 1.02-1.25, $\mathrm{p}=0.019$ ), PAPP-A level (OR 0.31, CI 95\% 0.17-0.59, $\mathrm{p}=0.0003$ ) and medically assisted procreation $(\mathrm{OR}=3.75$, CI 95\% 1.18-11.90, $\mathrm{p}=0.025)$. These findings are detailed in Table 3, Figs. 2 and 3.

\section{Discussion}

\section{Principal findings of the study}

Our study has shown that in singleton pregnancy with a normal first trimester ultrasound examination and an atypical value of first trimester serum assay i.e. HCG $<0.25 \mathrm{MoM}, \mathrm{HCG}>5.0 \mathrm{MoM}$ and/or PAPP-A $<0.25$ MoM, PAPP-A > 2.5 MoM, cfDNA assay has a low failure

Table 3 Results of the logistic regression concerning IUGR < 5th percentile and maternal characteristics

\begin{tabular}{llll}
\hline Predictive factor & Odds ratios & Cl 95\% & $\mathbf{p}$ \\
\hline Maternal age & 1.0677 & $0.9896-1.1521$ & 0.0910 \\
Fetal fraction & 0.8727 & $0.7908-0.9631$ & 0.0068 \\
Gestationnal age & 1.1289 & $1.0202-1.2491$ & 0.0189 \\
HCG level & 1.0822 & $0.9487-1.2344$ & 0.2395 \\
Caucasian origin & 2.1622 & $0.5999-7.7932$ & 0.2385 \\
PAPP-A level & 0.3127 & $0.1660-0.5891$ & 0.0003 \\
Multiparity & 1.0451 & $0.5179-2.1088$ & 0.9020 \\
AMP & 3.7490 & $1.1810-11.9007$ & 0.0249 \\
Maternal weight & 0.9958 & $0.9714-1.0209$ & 0.7417 \\
\hline
\end{tabular}

$C l$ confidence interval, HCG human chorionic gonadotropin, PAPP-A pregnancyassociated plasma protein $\mathrm{A}, A M P$ assisted medical procreation
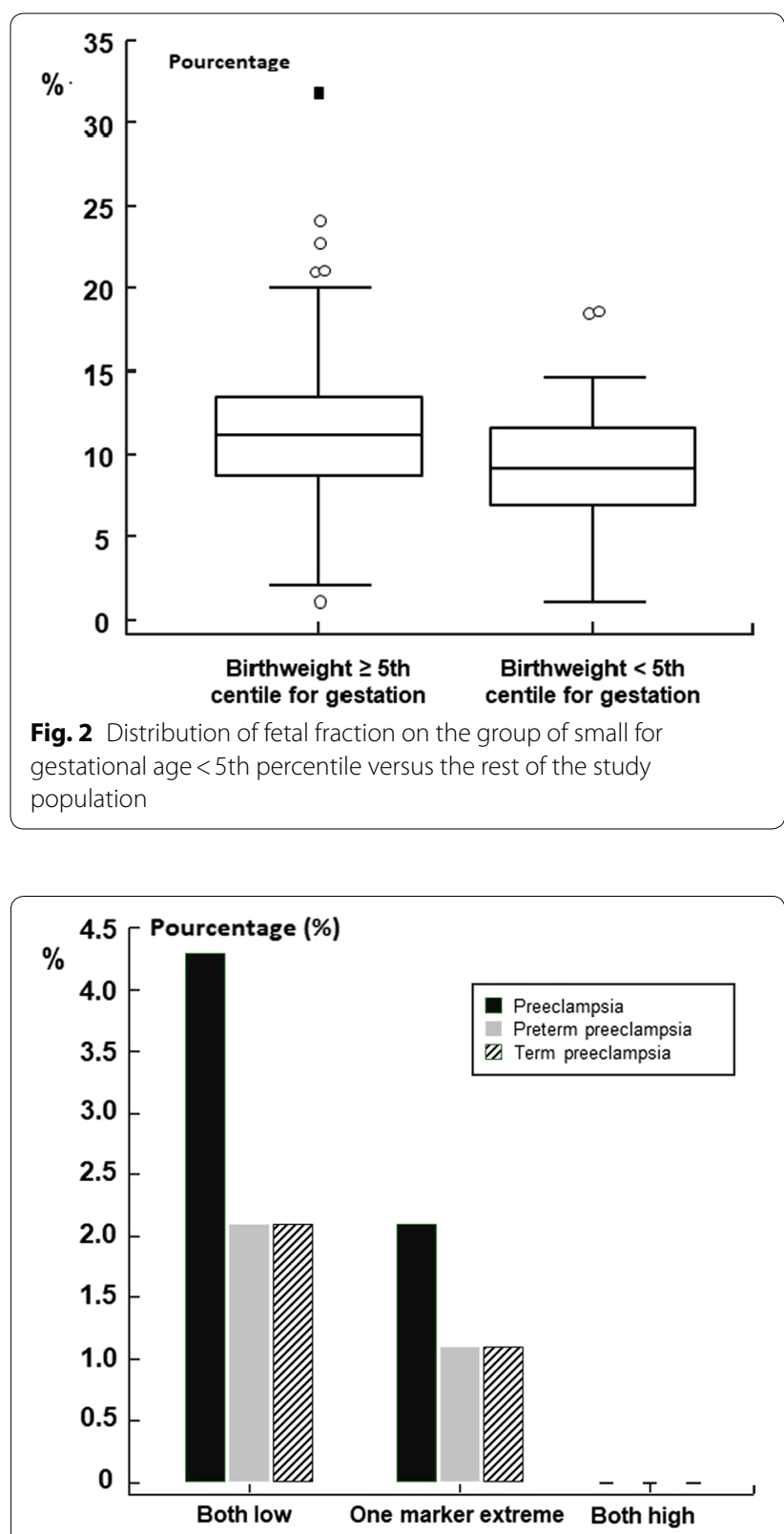

Fig. 3 Subgroup study for correlation with preeclampsia

rate and an excellent performance in screening for major trisomies. CfDNA can therefore be used as a screening test is this specific population. Further, we did not show 
a significant association between atypical biochemical markers and the occurrence of PE but an association between fetal fraction level and birthweight below the 5 th percentile for gestational age.

\section{Comparison with results of previous studies}

Patients with atypical first trimester screening serum results are at higher risk of chromosomal anomalies than general population [3]. Our aim was to explore whether cfDNA assay could be interesting in this specific population. Indeed, we found that this test has an excellent sensitivity and specificity for screening for major trisomies, and encourages us using this test for these patients. To our knowledge, this is the first study exploring the usefulness and reliability of cfDNA in patients with atypical serum results.

One of the fears around the widening use of cfDNA is to ignore other chromosomal anomalies than trisomy 21, 18 and 13, since the number of invasive procedures for fetal karyotype is reduced. In 2014, Petersen et al. reported a wide observational study based on a national database of 193,000 patients in Denmark showing that within patients with a chromosomal anomaly on karyotype, $23 \%$ of them would have been missed by cfDNA, but all of them were screened by ultrasound follow up [18]. Lindquist et al. also reported a series where the risk of missing another chromosomal anomaly was reduced by $90 \%$ when offering invasive procedure to patients with high combined risk, HCG or PAPP-A results below 0.2 MoM or any ultrasound anomaly [19]. Our results tend to reinforce the idea that the use of cfDNA does not inflate the risk of missing other chromosomal anomalies, even in this particular population, as only 4 patients were concerned, all diagnosed by ultrasound follow-up.

Due to its excellent performance rate, it has been suggested to simply remove the first trimester combined risk calculation, and directly offer cfDNA assay to all pregnant women [20]. Nevertheless, by applying such strategy, one could argue that we would miss a certain number of information concerning pregnancy risks, including vascular complications, as shown by Dukhovny et al. [21]. Indeed, it is suggested that patients with low PAPP-A level are exposed to higher risk of PE and PIH [12, 22-24], as well as IUGR [22, 23]. A low level of HCG could also be associated with a high risk of IUGR [22, 25, 26].

Although literature on the subject is rich, a large body of research have shown that the best strategy to predict and prevent occurrence of PE is based on a model taking into account maternal characteristics, physical and biochemical markers including measurement of placental growth factor rather than PAPP-A or HCG [27-32].
Several authors have explored a possible link between cfDNA assay and vascular complications, studying in particular the fetal fraction of cfDNA calculated for each patient. The main physiopathological hypothesis behind this link is that PE could cause an oxidative stress, which increases placental apoptosis [33] and cfDNA spreading. Therefore, the level of placental DNA should increase in maternal blood for these patients [11,34-36]. It has been shown that this change in fetal fraction occurs up to 3 weeks before the first clinical symptoms of vascular complications [11]. Although this theory seems logical, clinical findings in literature are heterogeneous, as several authors find a lower rate of fetal fraction for these patients [37-39]. Other authors only find a link between fetal fraction and early PE $[9,36]$. In our study, there was no significant association between fetal fraction and the occurrence of PIH or PE, due to a very low incidence of these maternal vascular events, and therefore a lack of statistical power.

Concerning fetal growth restriction, we found a significant association with a low fetal fraction. Previous authors have shown an association between low fetal fraction and IUGR $<37$ weeks [38].

\section{Implication for clinical practice}

CfDNA was initially promoted as a second-line test for pregnancies already at high risk of major trisomies based on conventional screening tests [40]. CfDNA is now considered as an acceptable first-line screening test and some countries like Belgium introduced it to all pregnant women at any background risk, yet the biochemistry test is not used any more as it cannot be cumulated for reimbursement with the use of cfDNA. There may be 2 concerns in such a strategy: first, the performance of cfDNA in patients with atypical biochemical results and second, the risk of reduction in the detection of atypical chromosome abnormalities previously identified through diagnostic testing after atypical biochemistry. Our study dismissed both of these concerns and as a consequence showed the possibility of not using any more PAPP-A and HCG in the first trimester screening for major trisomies.

\section{Strength and limitations}

The strength of our study is that it is a multicentric study, concerning patients from all over the country, which makes our cohort representative of the general French population and leads us to think that these results can be extrapolated. Further, we managed to obtain a large percentage of pregnancy outcome, with only $4.2 \%$ of lost to follow up, thanks to a wide respond from health care practitioners all over France. 
A limitation of our study is that the low incidence of $\mathrm{PIH}$ and PE did not allow us to obtain a sufficient statistical power to conclude on a link between vascular events and fetal fraction in cfDNA. On the other hand, our study was not primarily designed to study this association, which would have been better done if all cases with normal biochemistry results were also included in this study. Another limitation on this point is the fact that our cohort only implied patients with atypical results of HCG and/or PAPP-A, without any control group. Nevertheless, the aim of our work was not to prove the higher risk of vascular complications in this group compared to controls, which is widely established in literature, but to specify the potential contribution of cfDNA in this topic.

\section{Conclusion}

Performance of cfDNA assaying for trisomy 21 in a cohort of patients with atypical first trimester screening serum results seem to be similar to that reported in the general population. The number of cases of trisomies 18 and 13 is at the moment too small for accurate assessment of predictive performance of the cfDNA assay in this particular population. In the coming years, we may witness a decrease in the price of cfDNA assaying, especially with the introduction of new affordable technologies that may compete with the price of the biochemical tests [41]. In many advanced countries, this may be the end of the use of PAPP-A and HCG in the first trimester screening for major trisomies.

\begin{abstract}
Abbreviations
AMP: assisted medical procreation; cfDNA: cell free DNA; Cl: confidence interval; HCG: human chorionic gonadotropin; IUGR: intra uterine growth restriction; MoM: multiple of median; NIPT: non invasive prenatal testing; OR: odd ratio; PAPP-A: pregnancy-associated plasma protein-A; PE: preeclampsia; $\mathrm{PIH}$ : pregnancy induced hypertension; WG: week of gestation.
\end{abstract}

\section{Acknowledgements}

The authors thank Martine Olivi, Sandrine Moukoury and Ramdane Mallek for their technical assistance, and David Marsh for language editing.

\begin{abstract}
Authors' contributions
$J C, A V, A D$ and $A B$ collected, analyzed and interpreted the patient data. JC was the major contributor in writing the manuscript. $A B$ coordinated the team work and was a major contributor in writing the manuscript. JMC performed and interpreted the CfDNA tests and revised the manuscript. JCJ analyzed and interpreted the patient data, performed all statistical analyses and revised the
\end{abstract} manuscript. All authors read and approved the final manuscript.

\section{Funding}

The authors declare that they have no funding sources for this study.

\section{Availability of data and materials}

The datasets used and/or analysed during the current study are available from the corresponding author on reasonable request.

\section{Ethics approval and consent to participate}

In line with French regulations regarding prenatal diagnosis, written informed consent was obtained from all patients. CERBA Laboratory is authorized by the
Regional Health Agency to perform cfDNA screening tests. This research was approved by The Ethical Review Committee of the French CEROG (submission number CEROG 2018-OBST-0103).

\section{Consent for publication}

Not applicable.

\section{Competing interests}

The authors declare that they have no competing interests.

\section{Author details \\ 1 Service de Gynécologie-Obstétrique, Hôpital Antoine Béclère, AP-HP, 157 Rue de la Porte de Trivaux, 92140 Clamart, France. ${ }^{2}$ Université Paris Saclay, 91190 , Saint-Aubin, France. ${ }^{3}$ Department of Obstetrics and Gynecology, University Hospital Brugmann, Université Libre de Bruxelles, Brussels, Belgium. ${ }^{4}$ Labora- toire CERBA, Saint-Ouen l'Aumône, France.}

Received: 3 Auqust 2019 Accepted: 22 November 2019

Published online: 28 November 2019

\section{References}

1. Nicolaides KH, Syngelaki A, Ashoor G, Birdir C, Touzet G. Noninvasive prenatal testing for fetal trisomies in a routinely screened first-trimester population. Am J Obstet Gynecol. 2012;207(374):e1-6.

2. Rieder W, White S, McGillivray G, Hui L. Contemporary prenatal aneuploidy screening practice in Australia: frequently asked questions in the cell-free DNA era. Aust N Z J Obstet Gynaecol. 2018;58:397-403.

3. Muller F, Dreux S, Czerkiewicz I, Bernard M, Guibourdenche J, Lacroix I, et al. Down syndrome maternal serum screening: results' comments recommended by accredited biologists. J Gynecol Obstet Biol Reprod (Paris). 2014:43:671-9.

4. Gagnon A, Wilson RD. Society of obstetricians and gynaecologists of Canada genetics committee. Obstetrical complications associated with abnormal maternal serum markers analytes. J Obstet Gynaecol Can. 2008;30:918-32.

5. Huang T, Hoffman B, Meschino W, Kingdom J, Okun N. Prediction of adverse pregnancy outcomes by combinations of first and second trimester biochemistry markers used in the routine prenatal screening of Down syndrome. Prenat Diagn. 2010;30:471-7.

6. Spencer K, Yu CKH, Cowans NJ, Otigbah C, Nicolaides KH. Prediction of pregnancy complications by first-trimester maternal serum PAPP-A and free beta-hCG and with second-trimester uterine artery Doppler. Prenat Diagn. 2005;25:949-53.

7. Cuckle H, Arbuzova S, Spencer K, Crossley J, Barkai G, Krantz D, et al. Frequency and clinical consequences of extremely high maternal serum PAPP-A levels. Prenat Diagn. 2003;23:385-8.

8. Gil MM, Accurti V, Santacruz B, Plana MN, Nicolaides KH. Analysis of cell-free DNA in maternal blood in screening for aneuploidies: updated meta-analysis. Ultrasound Obstet Gynecol. 2017;50:302-14.

9. Illanes S, Parra M, Serra R, Pino K, Figueroa-Diesel H, Romero C, et al. Increased free fetal DNA levels in early pregnancy plasma of women who subsequently develop preeclampsia and intrauterine growth restriction. Prenat Diagn. 2009;29:1118-22.

10. Jakobsen TR, Clausen FB, Rode L, Dziegiel MH, Tabor A. Identifying mild and severe preeclampsia in asymptomatic pregnant women by levels of cell-free fetal DNA. Transfusion (Paris). 2013;53:1956-64.

11. Levine RJ, Qian C, Leshane ES, Yu KF, England LJ, Schisterman EF, et al. Two-stage elevation of cell-free fetal DNA in maternal sera before onset of preeclampsia. Am J Obstet Gynecol. 2004;190:707-13.

12. Kim SY, Kim HJ, Park SY, Han YJ, Choi JS, Ryu HM. Early prediction of hypertensive disorders of pregnancy using cell-free fetal DNA, cell-free total DNA, and biochemical markers. Fetal Diagn Ther. 2016;40:255-62.

13. Viossat $P$, Dommergue $M$, Lansac J. Report of the French "conférence nationale de l'échographie obstétricale et fœtale" (CNEOF) —recommendations for focused prenatal ultrasound. Gynecol Obstet Fertil. 2015:43:469-71.

14. Spencer K, Staboulidou I, Nicolaides KH. First trimester aneuploidy screening in the presence of a vanishing twin: implications for maternal serum markers. Prenat Diagn. 2010;30:235-40. 
15. Mamelle N, Vendittelli F, Rivière $O$, Crenn-Hébert C, Lémery D, Marès P, et al. Prenatal health in 2002-2003. Survey of medical practice. Results from the Audipog sentinel network. Gynecol Obstet Fertil. 2004;32(1):4-22.

16. Benachi A, Letourneau A, Kleinfinger P, Senat M-V, Gautier E, Favre R, et al. Cell-free DNA analysis in maternal plasma in cases of fetal abnormalities detected on ultrasound examination. Obstet Gynecol. 2015;125:1330-7.

17. Kim SK, Hannum G, Geis J, Tynan J, Hogg G, Zhao C, et al. Determination of fetal DNA fraction from the plasma of pregnant women using sequence read counts. Prenat Diagn. 2015;35:810-5.

18. Petersen OB, Vogel I, Ekelund C, Hyett J, Tabor A, et al. Potential diagnostic consequences of applying non-invasive prenatal testing: populationbased study from a country with existing first-trimester screening. Ultrasound Obstet Gynecol. 2014;43:265-71.

19. Lindquist A, Poulton A, Halliday J, Hui L. Prenatal diagnostic testing and atypical chromosome abnormalities following combined first-trimester screening: implications for contingent models of non-invasive prenatal testing. Ultrasound Obstet Gynecol. 2018;51:487-92.

20. Kagan KO, Sroka F, Sonek J, Abele H, Lüthgens K, Schmid M, et al. Firsttrimester risk assessment based on ultrasound and cell-free DNA vs combined screening: a randomized controlled trial. Ultrasound Obstet Gynecol. 2018;51:437-44.

21. Dukhovny S, Zera C, Little SE, McElrath T, Wilkins-Haug L. Eliminating first trimester markers: will replacing PAPP-A and BhCG miss women at risk for small for gestational age? J Matern-Fetal Neonatal Med Off. 2014;27:1761-4.

22. Hourrier S, Salomon LJ, Dreux S, Muller F. Screening for adverse pregnancy outcome at early gestational age. Clin Chim Acta. 2010:411:1547-52.

23. D'Antonio F, Rijo C, Thilaganathan B, Akolekar R, Khalil A, Papageourgiou $A$, et al. Association between first-trimester maternal serum pregnancyassociated plasma protein-A and obstetric complications. Prenat Diagn. 2013;33:839-47.

24. Luewan S, Teja-Intr M, Sirichotiyakul S, Tongsong T. Low maternal serum pregnancy-associated plasma protein-A as a risk factor of preeclampsia. Singapore Med J. 2018;59:55-9.

25. Dugoff L, Hobbins JC, Malone FD, Porter TF, Luthy D, Comstock CH, et al. First-trimester maternal serum PAPP-A and free-beta subunit human chorionic gonadotropin concentrations and nuchal translucency are associated with obstetric complications: a population-based screening study (the FASTER Trial). Am J Obstet Gynecol. 2004;191:1446-51.

26. Zhong Y, Zhu F, Ding Y. Serum screening in first trimester to predict pre-eclampsia, small for gestational age and preterm delivery: systematic review and meta-analysis. BMC Pregnancy Childbirth. 2015;15:191.

27. O'Gorman N, Wright D, Poon LC, Rolnik DL, Syngelaki A, Wright A, et al. Accuracy of competing-risks model in screening for pre-eclampsia by maternal factors and biomarkers at 11-13 weeks' gestation. Ultrasound Obstet Gynecol. 2017;49:751-5.

28. Tan MY, Syngelaki A, Poon LC, Rolnik DL, O'Gorman N, Delgado JL, et al. Screening for pre-eclampsia by maternal factors and biomarkers at 11-13 weeks' gestation. Ultrasound Obstet Gynecol. 2018;52(2):186-95.
29. Tan MY, Poon LC, Rolnik DL, Syngelaki A, de Paco Matallana C, Akolekar R, et al. Prediction and prevention of small-for-gestational-age neonates: evidence from SPREE and ASPRE. Ultrasound Obstet Gynecol. 2018;52(1):52-9.

30. Guizani M, Valsamis J, Dutemeyer V, Kang X, Ceccotti V, Khalife J, et al. First-trimester combined multimarker prospective study for the detection of pregnancies at a high risk of developing preeclampsia using the fetal medicine foundation-algorithm. Fetal Diagn Ther. 2018;43(4):266-73.

31. Rolnik DL, Wright D, Poon LC, Gorman N, Syngelaki A, de Paco Matallana $C$, et al. Aspirin versus placebo in pregnancies at high risk for preterm preeclampsia. N Engl J Med. 2017;377(7):613-22.

32. Wright D, Rolnik DL, Syngelaki A, de Paco Matallana C, Machuca M, de Alvarado $\mathrm{M}$, et al. Aspirin for evidence-based preeclampsia prevention trial: effect of aspirin on length of stay in the neonatal intensive care unit. Am J Obstet Gynecol. 2018;218(6):612.e1-6.

33. Taglauer ES, Wilkins-Haug L, Bianchi DW. Review: cell-free fetal DNA in the maternal circulation as an indication of placental health and disease. Placenta. 2014;35(Suppl):S64-8.

34. Sekizawa A, Jimbo M, Saito H, Iwasaki M, Matsuoka R, Okai T, et al. Cellfree fetal DNA in the plasma of pregnant women with severe fetal growth restriction. Am J Obstet Gynecol. 2003;188(2):480-4.

35. Cotter AM, Martin CM, O'leary JJ, Daly SF. Increased fetal DNA in the maternal circulation in early pregnancy is associated with an increased risk of preeclampsia. Am J Obstet Gynecol. 2004;191(2):515-20.

36. Sifakis S, Koukou Z, Spandidos DA. Cell-free fetal DNA and pregnancyrelated complications (review). Mol Med Rep. 2015;11(4):2367-72.

37. Krishna I, Badell M, Loucks TL, Lindsay M, Samuel A. Adverse perinatal outcomes are more frequent in pregnancies with a low fetal fraction result on noninvasive prenatal testing. Prenat Diagn. 2016;36(3):210-5.

38. Rolnik DL, da SilvaCosta F, Lee TJ, Schmid M, McLennan AC. Association between fetal fraction on cell-free DNA testing and first trimester markers for pre-eclampsia. Ultrasound Obstet Gynecol. 2018;52:722-7.

39. Suzumori N, Sekizawa A, Ebara T, Samura O, Sasaki A, Akaishi R, et al. Fetal cell-free DNA fraction in maternal plasma for the prediction of hypertensive disorders of pregnancy. Eur J Obstet Gynecol Reprod Biol. 2018;224:165-9.

40. Nicolaides KH, Wright D, Poon LC, Syngelaki A, Gil MM. First-trimester contingent screening for trisomy 21 by biomarkers and maternal blood cell-free DNA testing. Ultrasound Obstet Gynecol. 2013;42:41-50.

41. Dahl F, Ericsson O, Karlberg O, Karlsson F, Howell M, Persson F, et al. Imaging single DNA molecules for high precision NIPT. Sci Rep. 2018;8:4549.

\section{Publisher's Note}

Springer Nature remains neutral with regard to jurisdictional claims in published maps and institutional affiliations.

\footnotetext{
Ready to submit your research? Choose BMC and benefit from:

- fast, convenient online submission

- thorough peer review by experienced researchers in your field

- rapid publication on acceptance

- support for research data, including large and complex data types

- gold Open Access which fosters wider collaboration and increased citations

- maximum visibility for your research: over 100M website views per year
}

At BMC, research is always in progress.

Learn more biomedcentral.com/submissions 